\title{
Two Dimensional Modeling of Basaltic Rocks Intrusion Based On The Local Magnetic Anomalies Data In Jatilawang District Banyumas Regency
}

\author{
Sehah ${ }^{*}$ Sukmaji Anom Raharjo, and Urip Nurwijayanto Prabowo \\ Study Program of Physics, Faculty of Mathematic and Natural Sciences, Jenderal Soedirman \\ University, Street of dr. Suparno no.61, Purwokerto, Central Java, Indonesia \\ *sehahallasimy@yahoo.com
}

\begin{abstract}
Two dimensional modeling to basaltic rocks intrusion in Pekuncen and Karanglewas Villages Jatilawang District, Banyumas Regency, Central Java based on the local magnetic anomalies data has been carried out in March - June 2020. The amount of magnetic data obtained from the acquisition in the field was 239 data stretching in the position of $109.107222^{\circ}-$ $109.134944^{\circ} \mathrm{E}$ and $7.561361^{\circ}-7.577306^{\circ} \mathrm{S}$, with the local magnetic anomalies values ranging of $-2,961.11-1,516.31 \mathrm{nT}$. To model anomalous sources in the subsurface in two dimensions, then the local magnetic anomalies data is transformed into pseudogravity anomalies data, so that anomalous value can be obtained as $-27.815-41.087 \mathrm{mGal}$. Based on the pseudogravity anomalous map, the basaltic rock intrusion is interpreted to be located in the eastern part of the research area, so modeling of anomalous sources is conducted in this area. The results of 2Dmodeling to local magnetic anomalies data indicate the presence of anomalous object interpreted as basaltic rock intrusion with magnetic susceptibility contrast value of $0.0223 \mathrm{cgs}$, located at depth of $52.61-505.97 \mathrm{~m}$ and a lateral length of $1777.94 \mathrm{~m}$. This rock intrudes sediment rock from the Halang Formation and is connected to other basaltic rock near the surface with magnetic susceptibility contrast value of $0.0165 \mathrm{cgs}$, located at depth of $1.94-80.90 \mathrm{~m}$ and lateral length of $751.83 \mathrm{~m}$. The results of lithological interpretation are in accordance with the geological information of the research area.
\end{abstract}

Keywords: basaltic rocks intrusion, magnetic anomalies, magnetic susceptibility, Jatilawang

\section{INTRODUCTION}

Pekuncen and Karanglewas are villages located in Jatilawang District Banyumas Regency Central Java. The villages are located about $3 \mathrm{~km}$ south the City of Jatilawang District. The topography of the two villages consists of hills and lowlands. Hilly areas in the south of the villages are used more for tree crops, whereas the lowlands in the north which are deposited by the Lopasir River are used for residential areas, rice fields, and customary land ${ }^{[1]}$. This village is estimated to store a large potential of natural resources, namely basaltic rocks. Basaltic rocks spread unevenly; where some are buried and exposed on the surface. Basaltic rock is an igneous rock that is dark, heavy, contains a lot of iron mineral, and a little mineral content of volcanic silica. Basaltic rock is very well used for building materials because of its large density. Figure 1 shows the outcrops of basaltic rocks which are exposed on the surface of Pekuncen and Karanglewas Villages, Jatilawang District. 


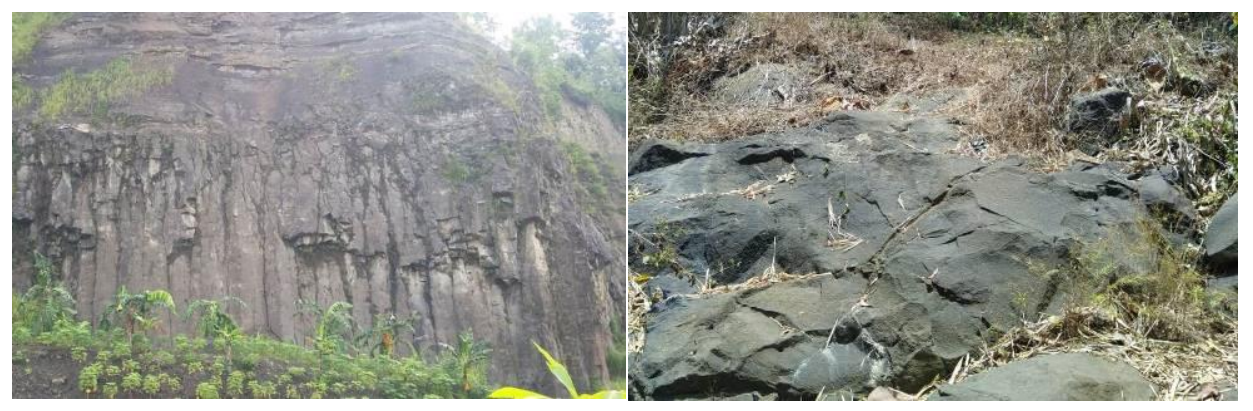

Figure 1. Outcrops of basaltic rocks that are exposed on the surface of Pekuncen and Karanglewas Villages, Jatilawang District, Banyumas Regency

Mapping the distribution of basaltic rocks in Pekuncen and Karanglewas Villages, District of Jatilawang is needed to develop regulations that govern the mining of basaltic rocks in these areas. In addition, this mapping is also useful to qualitatively localize the presence of dominant basaltic rocks intrusion. One of the geophysical exploration methods that can be used to explore and map basaltic rocks in an area is a magnetic survey ${ }^{[2]}$. This survey has a high sensitivity to basaltic rocks, so that basaltic rocks are easily detected. This is related to the large iron mineral content in these rocks, so that the rocks tend to be ferromagnetic [3]. In its application, a magnetic survey uses the quantity of magnetic susceptibility as a tool to identify subsurface rocks types through modeling and interpretation ${ }^{[4,5] \text {. }}$

The research began with magnetic data acquisition in the research area. The obtained total magnetic field strength data, then be corrected and reduced through several stages, so that local magnetic anomalies data are obtained ${ }^{[6,7]}$. The local magnetic anomalies data are a representation of geological conditions or subsurface rocks that are local and shallow. These local magnetic anomalies data were transformed to obtain pseudogravity anomalies data. The pseudogravity anomalous map can be applied qualitatively to estimate the location of basalt rocks buried in the subsurface. In this research, a pseudogravity anomalous map was used as reference in 2D-forward modeling to the local magnetic anomalies data, so that the lithological section model which illustrates the subsurface rocks section including basaltic rocks intrusion in the research area was obtained easily ${ }^{[8]}$.

Transformation of magnetic anomalies data that can be applied to clarify the location of objects or subsurface anomalous sources which are the target of research is pseudogravity transformation ${ }^{[9]}$. The basic principle of this transformation is to use the Poisson relation. Poisson's theorem relates the derivative of the gravity taken along the total magnetization vector direction and the magnetic potential due to a common, isolated source with constant density and magnetization distributions. Based on equation (2.5), the relation shows that the magnetic potential $V$ and the gravitational potential $U$ originating from an object that has the same magnetization and density can be expressed by formulation ${ }^{[10]}$ :

$$
V=-\frac{C_{m}}{\gamma} \frac{M}{\rho} \hat{m} \bullet \nabla_{P} U=-\frac{C_{m}}{\gamma} \frac{M}{\rho} g_{m}
$$

where $\rho$ is the density, $M$ is the intensity of magnetization, $m$ is the magnetization unit vector and $g_{m}$ is the component of the gravitational field in the direction of magnetization. To obtain a Poisson relation value, the values of $M$ and $\rho$ are assumed to be constant. The Poisson relation can be applied to convert magnetic anomalies data into gravity anomalies data, if the magnetization distribution can be replaced by density distribution identically, assuming the ratio of $M$ and $\rho$ values is fixed along with the source of the anomalous body 
${ }^{[10]}$. Based on the pseudogravity anomaly contour map, the distribution of basalt rocks in an area can be easily identified and mapped. Visually, this transformation process is shown in Figure 2. This research aims to model the basaltic rock intrusion in two dimensions based on the local magnetic anomalies data, considering the pseudogravity anomalous map and geological information.

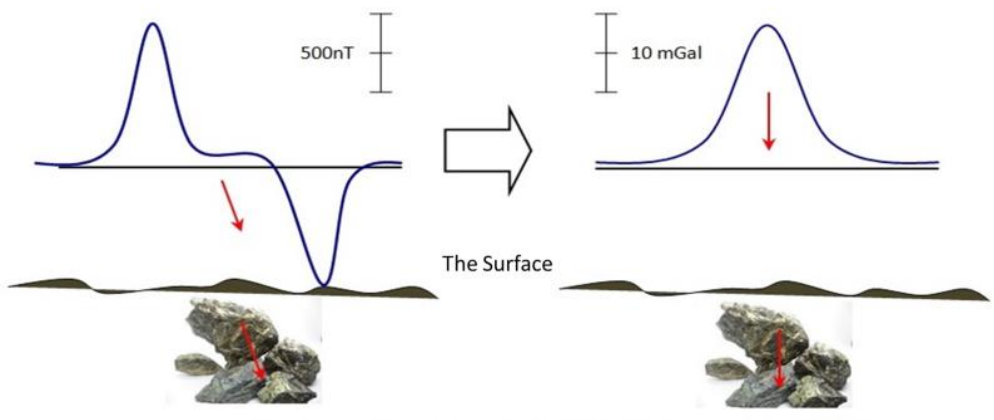

Figure 2. The basic principle of the process of pseudogravity transformation visually

\section{RESEARCH METHODS}

\section{Material and Equipment}

Materials and equipment needed in this research both in the field and in the laboratory, can be seen in full in Table 1.

Table 1. The equipment used in this research, both in the field and in the laboratory

\begin{tabular}{clr}
\hline No. & \multicolumn{1}{c}{ Equipment } & Quantity \\
\hline 1 & Proton Precession Magnetometers GSM-19T from GEM System & 1 unit \\
2 & Global Positioning System (GPS) from Garmin & 1 unit \\
3 & Geological Map of Banyumas-Cilacap Sheet & 1 sheet \\
4 & Topographical Map of Research Area using Google Earth Application & 1 sheet \\
5 & Compass & 1 unit \\
6 & Laptop and printer & 1 set \\
7 & Software Surfer version 8.0 & 1 piece \\
8 & Software Watfor 77 & 1 piece \\
9 & Software Mag2DC for Windows version 2.11 & 1 paket \\
\hline
\end{tabular}

\section{Location and Time}

The location of magnetic data acquisition is in Pekuncen and Karanglewas Villages, District of Jatilawang, Banyumas Regency, Central Java, Indonesia as shown in Figure 3. While the location of processing, modeling, and interpretation of magnetic anomalies data are the Electronic, Instrumentation, and Geophysics Laboratory, Jenderal Soedirman University Street of Dr. Suparno No. 61 Purwokerto Central Java, Indonesia. This research has been conducted in March - June 2020. 


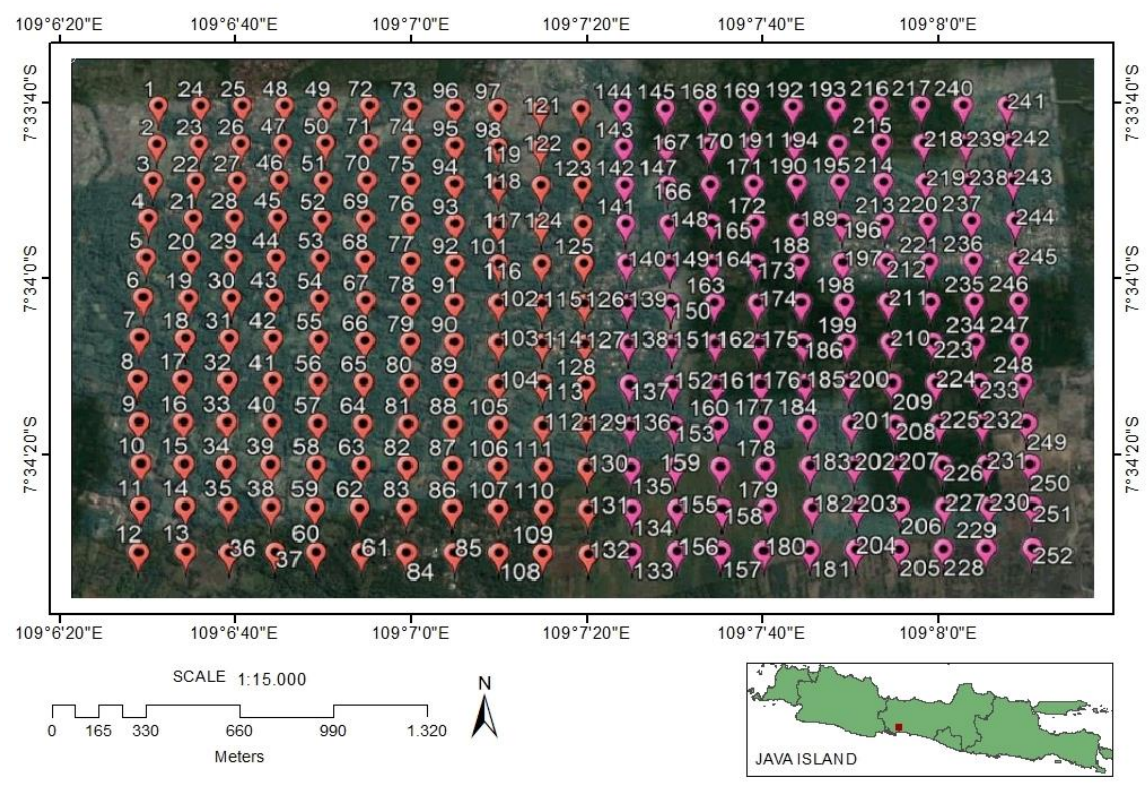

Figure 3. The research location map and distribution of magnetic data acquisition station points in the field

\section{Research Procedure}

Procedure in this research which has been carried out include magnetic data acquisition in the field, processing, modeling, and interpretation. The obtained data from acquisitions in the field are total magnetic field strength, the geographic position of station points, time, and geological or environmental conditions. Furthermore, the total magnetic field strength data $\left(B_{\mathrm{T}}\right)$ are corrected including daily correction $\left(B_{\mathrm{D}}\right)$ and earth's main magnetic field or IGRF correction $\left(B_{0}\right)$ to obtain total magnetic anomalies data $(\Delta B)$ with equation ${ }^{[11]}$ :

$$
\Delta B=B_{T} \pm \Delta B_{\text {Harian }}-B_{0}
$$

The total magnetic anomalies data from Equation (3) is still distributed on the topographic surface, so it needs to be transformed to a horizontal surface. The transformation process of magnetic anomalies data into a horizontal surface is carried out using the Taylor series approximation ${ }^{[10]}$. Equation (4) is expressed in terms of iteration, where $\Delta B\left(\lambda, \vartheta, h_{0}\right)$ that are anomalies data that distributed in the horizontal surface can be estimated through the approach i.e. the value of $\Delta B\left(\lambda, \vartheta, h_{0}\right)$ obtained from iteration $i$-th can be used to estimate $\Delta B\left(\lambda, \vartheta, h_{0}\right)$ in the next iteration or $(i+1)$-th. The iteration process is carried out sufficiently, so that the values of $\Delta B\left(\lambda, \vartheta, h_{0}\right)$ obtained have shown to be convergent ${ }^{[10]}$.

$$
\Delta B\left(\lambda, \vartheta, h_{0}\right)^{[i+1]}=\Delta B(\lambda, \vartheta, h)-\sum_{n=0}^{\infty} \frac{\left(h-h_{0}\right)^{n}}{n !} \frac{\partial^{n}}{\partial z^{n}} \Delta B\left(\lambda, \vartheta, h_{0}\right)^{[i]}
$$

The magnetic anomalies data that are obtained from Equation (4) needs to be cleared from the regional magnetic effect, because the target of the research is the basalt rocks intrusion which is near the surface ${ }^{[12]}$. Regional magnetic anomalies data can be obtained through an upward continuation of magnetic anomalies data that has been distributed on a horizontal surface to a certain height, so that the anomalous data interval between one point to a point around it has shown a very subtle ${ }^{[13]}$. Regional magnetic anomalies data obtained, then corrected to the magnetic anomalies data that has been distributed in the horizontal surface to obtain local magnetic anomalies data, such as equation (5) ${ }^{[14]}$ : 


$$
\Delta B_{\text {Lokal }}=\Delta B\left(\lambda, \vartheta, h_{0}\right)-\frac{\Delta h}{2 \pi} \int_{-\infty-\infty}^{\infty} \int_{\sqrt{\left(\left(\lambda^{\prime}-\lambda\right)^{2}+\left(\vartheta^{\prime}-\vartheta\right)^{2}+\Delta h^{2}\right)^{3 / 2}}} d \lambda d \vartheta
$$

The right term is the regional magnetic anomalous resulting from the upward continuation and $\Delta h$ is the upward height ${ }^{[14]}$.

To localize the subsurface anomalous source that was the target of the research, the local magnetic anomalies data were transformed into pseudogravity anomalies data, using the formulation which has been explained in Equation (1). The pseudogravity anomalous map associated with density can be used to localize basaltic rock in the research area ${ }^{[15]}$. The pseudogravity anomalous map is used as a reference for 2D-forward modeling to the local magnetic anomalies data. Then the anomalous objects, geological structures, or subsurface rocks obtained from this modeling are then interpreted lithologically based on the magnetic susceptibilities values of rocks and geological information of the research area. Based on the results of interpretation; so the location, depth, and structure model of basaltic rocks intrusion in the research area can be obtained.

\section{RESULTS AND DISCUSSION}

\section{Magnetic Data Processing Results}

Total magnetic field strength of 239 locations was measured which stretches at a position of $109.107222^{\circ}-109.134944^{\circ} \mathrm{E}$ and $7.561361^{\circ}-7.577306^{\circ} \mathrm{S}$. Based on the results of data acquisition, the obtained total magnetic field strength ranged of $41804.58-46719.76$ nT. The total magnetic field strength data were corrected by daily and IGRF corrections, so that the total magnetic anomalies data can be obtained ranged of -3.175 .12 to 1.773 .76 nT. These total magnetic anomalies data are still distributed on the topographic. The data cannot be processed at the next, if the data are not reduced to a horizontal surface. The method used to reduce magnetic anomalies data from the uneven surface to the horizontal surface is through the Taylor Series approximation, such as Equation (4). This horizontal surface was chosen at an average topographic height, i.e. $102.69 \mathrm{~m}$ above the reference spheroid ${ }^{[10]}$. The contour maps of the total magnetic field strength and the total magnetic anomalous which has been distributed on a horizontal surface is shown in Figure 4.
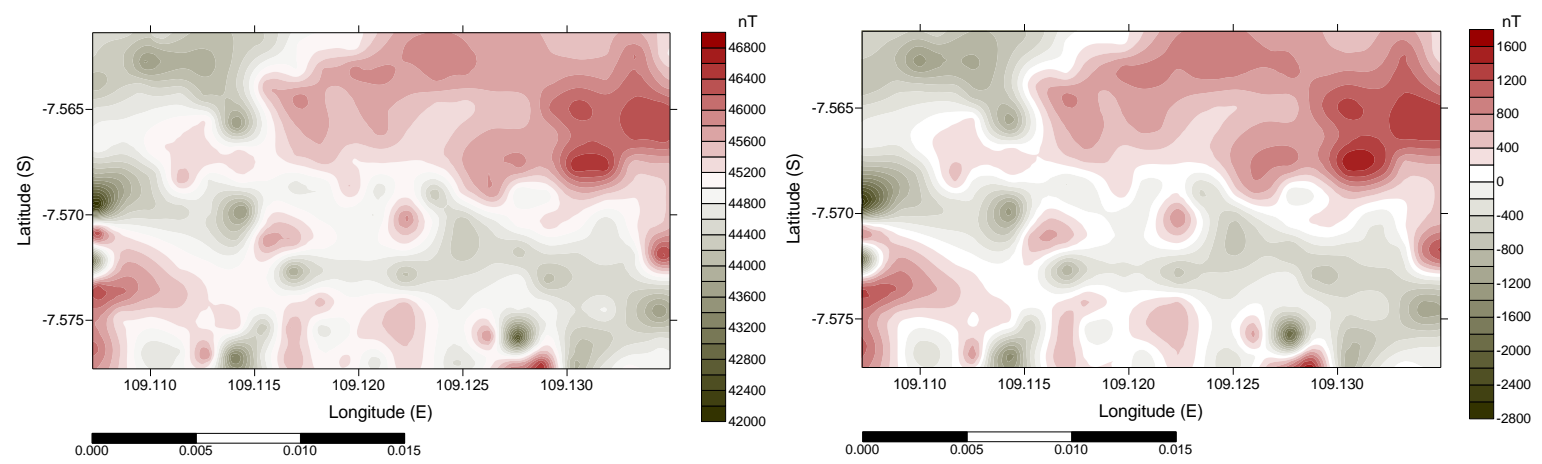

Figure 4. The contour maps of the total magnetic field strength and total magnetic anomalous which has been distributed on a horizontal surface

As explained in the Methods, the total magnetic anomalies data that has been distributed on the horizontal surface must be cleared of regional magnetic effects. Regional anomalies data are obtained through upward continuation to a certain height. Upward continuation is 
done, so that variation in magnetic anomalies data show a relatively fixed trend ${ }^{[13]}$. The analysis results to contours patterns of the upward continuation anomalous maps that are resulted show that the magnetic anomalous contour map at height of $3500 \mathrm{~m}$ has indicated a smooth and fix pattern, so that this map is determined as a regional magnetic anomaly. The regional magnetic anomalies data are removed from the total magnetic anomalies data that has been distributed on the horizontal surface to obtain the local magnetic anomalies data. The regional and local magnetic anomalies contours maps can be seen in Figure 5.
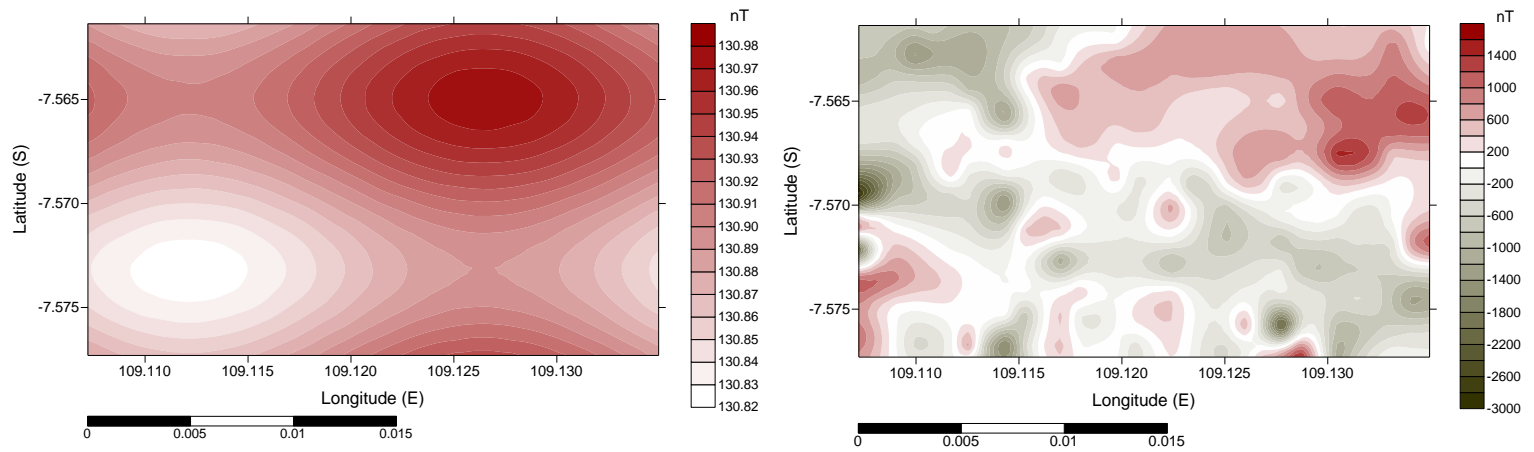

Figure 5. The regional and local magnetic anomalous contours maps of the research area

The local magnetic anomalous map such as Figure 5 still shows complicated anomalous closures. This complicates the interpretation process, especially quantitative interpretation which aims to model the subsurface anomalous sources, such as basalt rocks intrusion. To clarify the location of subsurface anomalous sources, then a pseudogravity transformation was applied ${ }^{[15]}$. Transformation is conducted by changing the magnetic anomalies data into pseudogravity anomalies data as explained in Method. Pseudogravity transformation is a technique to interpret magnetic anomalies data qualitatively ${ }^{[15]}$. The pseudogravity anomalies data obtained from this calculation have values ranging of $-115.94-124.29$ mGal, with contour map as shown in Figure 6. The pseudogravity anomalous contour map of the research area looks more simpler and informative than magnetic anomalous contour map before being transformed. Figure 6 indicates that the high pseudogravity anomalies are localized in the east of the research area, while the low anomalies are localized in the west area. Qualitatively the pseudogravity anomalous map is assumed to be associated with the density of the subsurface anomalous sources ${ }^{[9]}$. Therefore, basaltic rocks intrusion with high density is estimated to be localized in the high anomalous closure area.
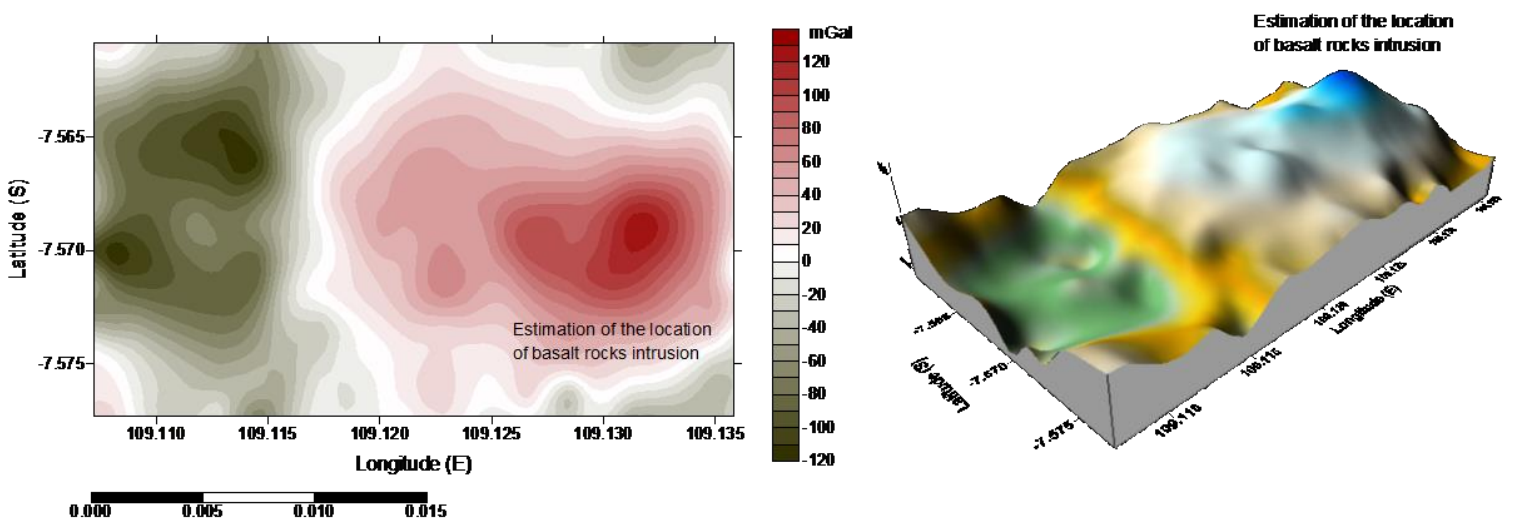

Figure 6. 2D and 3D pseudogravity anomalous map and estimation of the location of basaltic rocks intrusion

Based on Figure 6, the highest psesudogravity anomalies value is $124.29 \mathrm{mGal}$ which is located at a position of $109.131225 \mathrm{E}$ and $7.569342 \mathrm{~S}$. At that point and its surroundings, 
it is estimated that there is a very compact basaltic rock intrusion. In general, the presence of compact basaltic rocks intrusion is estimated to be present in the red closure zone on the pseudogravity anomalous contour map. This is in accordance with the geological map of the research area, as shown in Figure 7. The high value of pseudogravity anomalies at that point is thought to be sourced from basaltic rocks intrusion which is mostly located in the eastern part of the research area and a small part in the southwest. This information of this geological map is also in accordance with the local anomalous contour map, as shown in Figure 5.

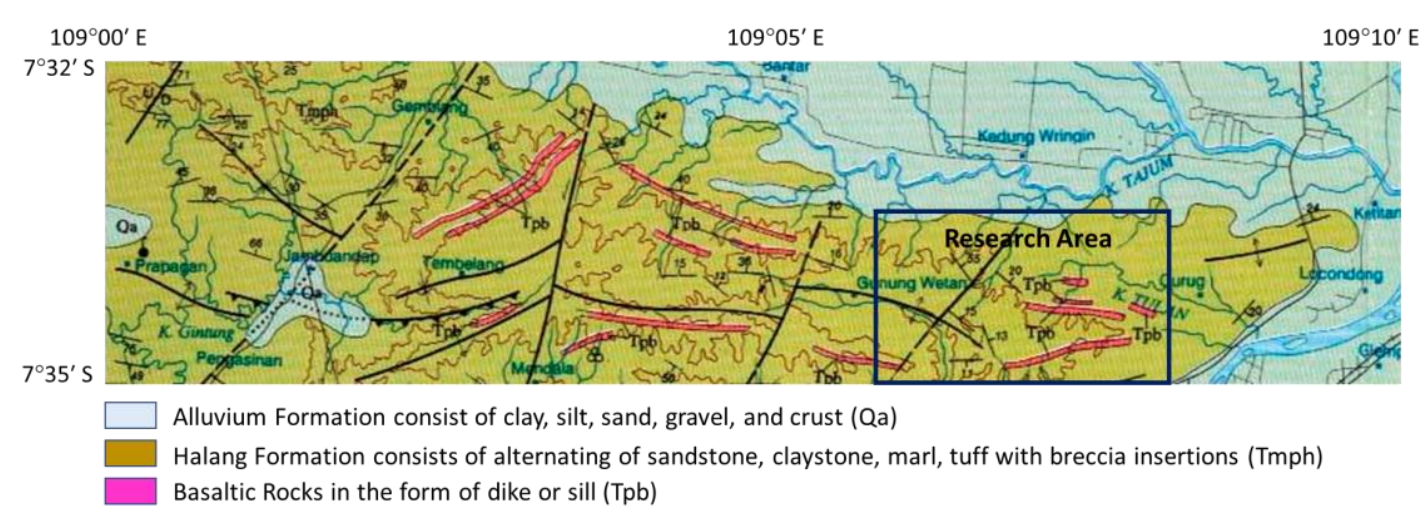

Figure 7. The geological map of the research area ${ }^{[17]}$

\section{Modeling and Interpretation Results}

2D-forward modeling of subsurface magnetic anomalous sources has been done using the Mag2DC for Windows 2.11 (freeware) application. The 2D-forward modeling steps have been explained in the Methods section. The determination of the position of the trajectory for modeling refers to the pseudogravity anomalous map that has been overlaid with the local magnetic anomalous contour map. In addition, the determination of this trajectory position is adjusted with a geological map, which shows the location of basaltic rock intrusion in the research area ${ }^{[16]}$. The modeling trajectory created on the local magnetic anomalous map and its anomalous profile are shown in Figure 8. Modeling is done on the local magnetic anomalies data, where the anomalies data are extracted from the trajectory using the Surfer 8 software. In this modeling, several parameters of the earth's magnetic field are needed; such as the IGRF value, the declination and inclination angles, and several other model parameters, which are fully shown in Table 2.
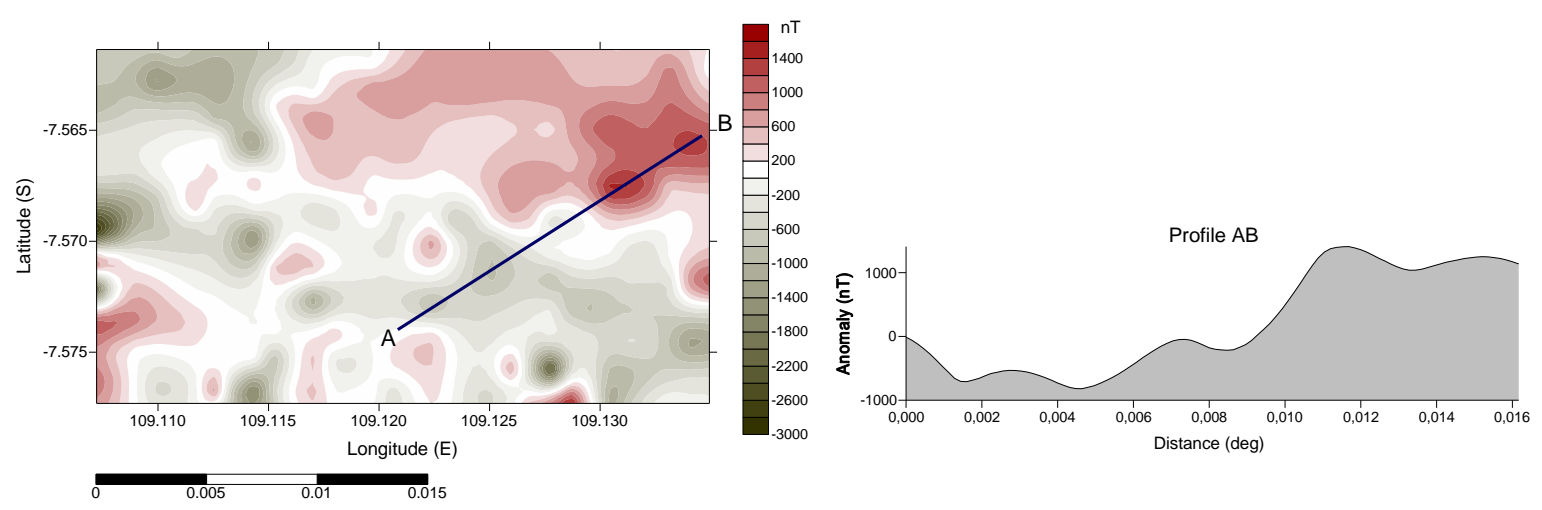

Figure 8. AB trajectory above the local magnetic anomalous contour map for $2 \mathrm{D}$-forward modeling and local magnetic anomalous profile along $\mathrm{AB}$ trajectory 
Table 2. Earth's magnetic field parameters and other parameters for modeling

\begin{tabular}{clc}
\hline No. & Parameters for Modeling & Values \\
\hline 1 & The IGRF value & $44946.00 \mathrm{nT}$ \\
2 & Declination angle & $0.69^{\circ}$ \\
3 & Inclination anle & $-31.74^{\circ}$ \\
4 & Profile bearing & $0.00^{\circ}$ \\
5 & Reference height & Topographic average \\
6 & Strike length & $100 \mathrm{~m}$ \\
7 & Position of trajectory & $109.120687 \mathrm{BT} ;-7.574151 \mathrm{LS}(\mathrm{A}) \& 109.134810 \mathrm{BT} ;$ \\
8 & Trajectory length & $-7.564978 \mathrm{LS}(\mathrm{B})$ \\
9 & Anomalies value interval & $1871,1 \mathrm{~m}$ \\
\hline
\end{tabular}

The results of 2D-forward modeling are five anomalous objects which are assumed to be subsurface rocks as shown in Figure 9. The results of interpretation for anomalous object models produce types of subsurface rocks which are equipped by magnetic susceptibility contrast values $(\Delta \chi)$, magnetic susceptibility values $(\chi)$, and depth of each rock, as can be seen in Table 3. This lithological interpretation still considers the geological information, especially the dominant rock formations in the research area. Based on the geological map, rock formations in the Pekuncen and Karanglewas Villages Jatilawang District Banyumas Regency are dominated by sediment rocks that are tertiary age from the Halang Formation (Tmph). This rock formation consists of alternating sandstone, claystone, marl, tuff with breccia insertions ${ }^{[16]}$. In the eastern of the research area, basaltic rocks intrusions in the form of sill or dike (Tpb) are commonly found. This information from the geological map is in accordance with the local magnetic anomalous contour map, where high and low magnetic anomalous closures are found in this area. As well as, the pseudogravity anomalous map also shows high anomalies in this area. This indicates the existence of anomalous sources with large magnetic susceptibility and density values, such as basaltic igneous rocks.

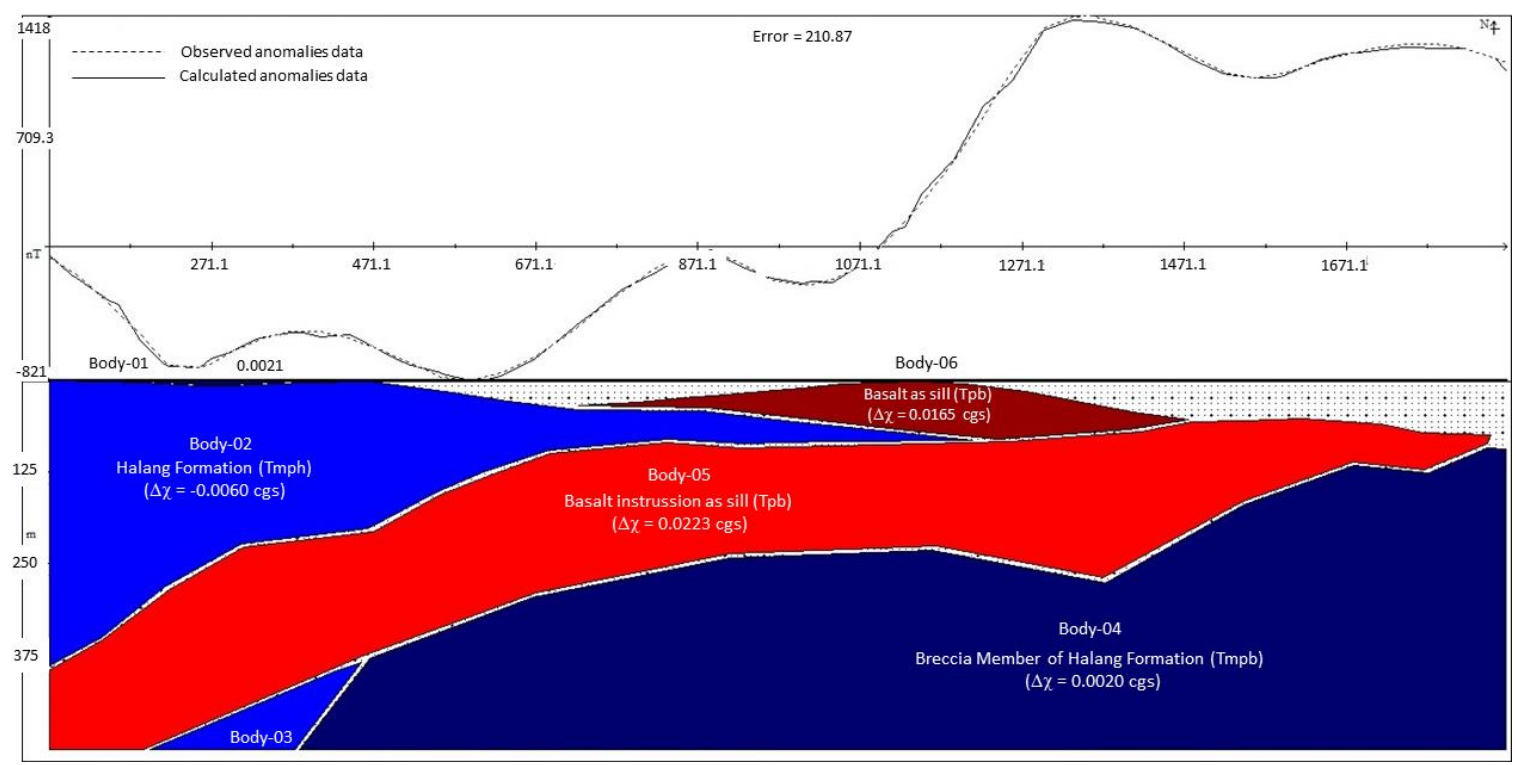

Figure 9. Results of 2D-forward modeling to local magnetic anomalies data along AB trajectory. 
Based on the results of 2D-forward modeling to the local magnetic anomalies data using Mag2DC for Windows 2.11 (freeware) shows the presence of compact basaltic rocks. In general basaltic rocks intrusion form sill structure which is parallel to the rocks bedding field. A very compact basaltic rock intrusion $(\Delta \chi=0.0223 \mathrm{cgs})$ is estimated at a depth of $52.61-505.97 \mathrm{~m}$ from the average topographic surface with a lateral length of $1777.94 \mathrm{~m}$. This basaltic rock intrusion breaks through sedimentary rocks from the Halang Formation which are consists of alternating sandstone, claystone, marl, and tuffs with insertions of breccia $(\Delta \chi=-0.0060 \mathrm{cgs})$ with a depth of $0-505.97 \mathrm{~m}$. This igneous rock intrusion turn to the left, thus forming another compact basaltic rock deposit $(\Delta \chi=0.0165 \mathrm{cgs})$ located near the surface with a depth of $1.94-80.90 \mathrm{~m}$ from the average topographic surface with a length of $751.83 \mathrm{~m}$. These basaltic rocks in the form of sill structures appear on the surface, so that form rocks outcrops as shown in Figure 1. Under the intrusion of basaltic rocks, there are a member of breccias rocks of the Halang Formation $(\Delta \chi=0.0020 \mathrm{cgs})$ that are interpreted to be located at a depth of $92.54-505.97 \mathrm{~m}$ and composed of breccias with andesite components, basaltic, and limestone. Breccias rocks are the result of weathering of igneous rocks, so the magnetic susceptibility is also relatively high ${ }^{[17]}$.

Table 3. The results of lithological interpretation to the model objects obtained in Figure 8

\begin{tabular}{|c|c|c|c|c|c|}
\hline No. & $\begin{array}{l}\text { Anomaly } \\
\text { Object }\end{array}$ & $\begin{array}{l}\text { Depth } \\
(\mathrm{m})\end{array}$ & $\begin{array}{c}\Delta \chi \\
(\mathrm{cgs})\end{array}$ & $\begin{array}{c}\chi \\
(\mathrm{cgs})\end{array}$ & Lithological Interpretation \\
\hline 1 & Body-01 & $0.00-6.57$ & 0.0021 & 0.0101 & $\begin{array}{l}\text { Compacted sandy claystone } \\
\text { with inserted by breccias }\end{array}$ \\
\hline 2 & Body-02 & $0.00-391.64$ & & & Halang Formation: alternating \\
\hline 3 & Body-03 & $386.57-505.97$ & -0.0060 & 0.0020 & $\begin{array}{l}\text { sandstone, claystone, marl, and } \\
\text { tuff with inserted by breccias }\end{array}$ \\
\hline 4 & Body-04 & $92.54-505.97$ & 0.0020 & 0.0100 & $\begin{array}{r}\text { Breccia members of the Halang } \\
\text { Formation: breccias with ande- } \\
\text { site components, basalt, and } \\
\text { limestone }\end{array}$ \\
\hline 5 & Body-05 & $52.61-505.97$ & 0.0223 & 0.0303 & Basaltic rock intrusion and de- \\
\hline 6 & Body-06 & $1.94-80.90$ & 0.0165 & 0.0245 & \\
\hline
\end{tabular}

Note: The average magnetic susceptibility value of rocks in the research area is estimated about $0.0080 \mathrm{cgs}$ (for the Halang Formation). Magnetic susceptibility $(\chi)$ of each subsurface rock is calculated based on the sum the average magnetic susceptibility and the contrast of the each rock magnetic susceptibility.

The results of this magnetic survey are supported by previous research. Geoelectric survey with resistivity method has been done in the research area in 2018 at a position of $7^{\circ} 34^{\prime} 2.9^{\prime \prime} \mathrm{S}$ and $109^{\circ} 7^{\prime} 15.9^{\prime \prime} \mathrm{E}$. The results of 1D-modeling of resistivity data at that point indicate several subsurface rocks layers; where compact basaltic rock intrusion is found at depth of $37.96-47.22 \mathrm{~m}$ with resistivity values of $36.11 \Omega \mathrm{m}$. Under the basaltic rocks, there are rocks that have a resistivity value of $6.29 \Omega \mathrm{m}$ which is interpreted as sand which acts as a deep groundwater aquifer. The result of the geoelectric survey has been followed up with drilling to a depth of $80 \mathrm{~m}$. Based on the result of sample test, basaltic rock was found at a depth of $37.96-47.22 \mathrm{~m}$ at that location point, as can be shown in Figure 10 [18]. 


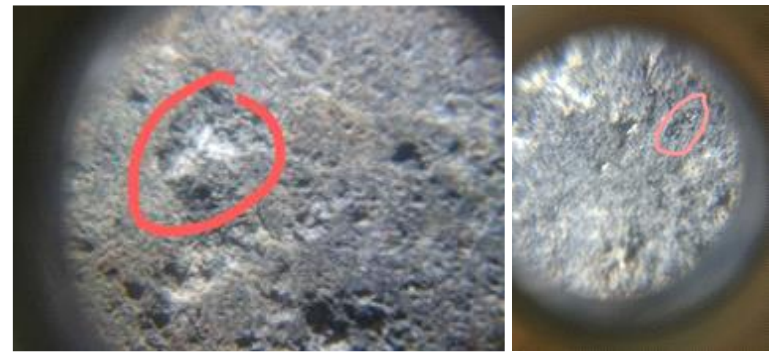

Figure 10. Basaltic rock samples from drilling results in the research area; appearance of the mineral content plagioclase (left) and amphibole (right) in rock samples

The structure of this rock igneous sample was identified to be massive, i.e. a structure that showed a uniformity. The massive structure is one of the structures of extrusive igneous rock; i.e. igneous rock which the freezing process takes place on the earth surface ${ }^{[19]}$. Based on the result of the analysis using a loop, this igneous rock sample has a mineral composition of plagioclase and amphibole. Based on the results of the mineral estimation, this extrusive igneous rock sample is interpreted as a basaltic rock ${ }^{[18]}$. The environment of basaltic rock formation in this area is thought to be a continental environment where a mantle plume or hotspot delivers enormous amounts of basaltic lava through the continental crust and up to Earth's surface. These eruptions can be from either vents or fissures. They have produced the largest basalt flows on the continents. The eruptions can occur repeatedly over millions of years, producing layer after layer of basalt stacked in a vertical sequence ${ }^{[20]}$.

\section{CONCLUSION}

The magnetic survey used to model basaltic rocks intrusion in two dimensions (2D) in the Pekuncen and Karanglewas Villages, Jatilawang District, Banyumas Regency, Central Java, Indonesia has been carried out in March - June 2020, based on the local magnetic anomalies data. The amount of magnetic data obtained from an acquisition in the field is 239 data, stretching in position of $109.107222^{\circ}-109.134944^{\circ} \mathrm{E}$ and $7.561361^{\circ}-$ $7.577306^{\circ} \mathrm{S}$. After some corrections and reductions are applied, then the local magnetic anomalies data are obtained with values ranging of $-2,961.11-1,516.31 \mathrm{nT}$. To model anomalous sources in the subsurface, first the local magnetic anomalies data is transformed into pseudogravity anomalies data, so that anomalous values can be obtained as of $-27.815-41.087 \mathrm{mGal}$. Based on the pseudogravity anomalous map, the basaltic rock intrusion is interpreted to be located in the eastern part of the research area.

Based on the pseudogravity anomalous map which is supported by geological information, the modeling has been conducted in the eastern part of the research area. The results of the modeling to the local magnetic anomalies data indicate the presence of anomalous objects interpreted as basaltic rock intrusion with magnetic susceptibility contrast value of 0.0223 cgs, located at depth of $52.61-505.97 \mathrm{~m}$ with a lateral length of $1777.94 \mathrm{~m}$ and form the sill structure. This basaltic rock intrudes sediment rocks from the Halang Formation and is connected with other basaltic rocks near the surface with magnetic susceptibility contrast value of $0.0165 \mathrm{cgs}$, depth of $1.94-80.90 \mathrm{~m}$, and a lateral length of $751.83 \mathrm{~m}$. The results of lithological interpretation have been in accordance with the geological information of the research area dan the results of the previous research. 


\section{ACKNOWLEDGEMENT}

The authors would like to thank the Rector and the Chairman of Research and Community Service Institute (LPPM) of Jenderal Soedirman University for the research funding that is provided. We thank the Head of Electronics, Instrumentation and Geophysics Laboratory of Jenderal Soedirman University for providing the Proton Precession Magnetometer (PPM) instrument. We also would like to express gratitude to the member of geophysical research groups of Physics Department, Jenderal Soedirman University for collaboration in data acquisition process.

\section{REFERENCES}

1 Wikipedia, 2019. Pekuncen, Jatilawang, Banyumas. Website. Tersedia pada alamat https://id.wikipedia.org/wiki/Pekuncen,_Jatilawang,_Banyumas\#p-search. Diakses pada tanggal 05 Nopember 2019.

2 Adagunodo, T.A., Sunmonu, L.A., Adeniji, A.A., 2015. An Overview of Magnetic Method in Mineral Exploration. Journal of Global Ecology and Environment (JoGEE), Vol. 3 (1): 13 - 28.

3 Vincent, A., Kassim, M., Charles, M., Willis, A., Gerald, M., 2013. Geophysical Exploration of Iron Ore Deposit in Kimachia Area in Meru County in Kenya, Using Gravity and Magnetic Techniques. International Journal of Science and Research (IJSR). Vol. 2 (11): $104-108$.

$4 \mathrm{Li}, \mathrm{Z}$. and G. Fu, 2019. Application of Magnetic Susceptibility Parameters in Research of Igneous Rock in Chepaizi. IOP Conf. Series: Journal of Physics: Conf. Series 1176 (2019) 042068.

5 Pastore, Z., C. Fichler, S.A. McEnroe, 2018. Magnetic Anomalies of The Mafic or Ultramafic Seiland Igneous Province. Norwegian Journal of Geology. Vol. 98 (1): 79 $-101$.

6 Sehah, Raharjo, S.A., dan Priyadi, P., 2016. Transformasi Pseudogravitasi Data Anomali Magnetik untuk Melokalisir Sumber Rembesan Minyak di Daerah Cipari Kabupaten Cilacap. Wahana Fisika, Vol. 1 (2): 99 - 110.

7 Sehah, S.A. Raharjo, dan I. Andriyanto, 2017. Exploration of Iron Sand at The Eastern Coastal of Binangun in Cilacap Regency Using Magnetic Survey, Indonesian Journal of Applied Physics (IJAP), Vol. 7 (2): 71 -81.

8 Quesnel, Y., Langlais, B., Sotin, C., Galdeano, A., 2008. Modelling and Inversion of Local Magnetic Anomalies. Journal of Geophysics and Engineering, Vol. 5 (2008) $387-400$.

9 Sehah, Raharjo, S.A., dan Prabowo, U.N., 2019. Penerapan Peta Anomali Pseudogravitasi untuk Interpretasi Sebaran Batuan Andesit di Desa Candiwulan Kecamatan Kutasari Kabupaten Purbalingga dan Sekitarnya. Seminar Nasional dan Call for Papers "Pengembangan Sumber Daya Perdesaan dan Kearifan Lokal Berkelanjutan IX" 19 - 20 November 2019. Purwokerto.

10 Blakely, R.J., 1995. Potential Theory in Gravity and Magnetic Applications. Cambridge University Press. New York, USA.

11 Sehah, Raharjo, S.A., dan Risyad, A., 2020. A Geophysical Survey with Magnetic Method for Interpretation of Iron Ore Deposits in the Eastern Nusawungu Coastal, Cilacap Regency Central Java Indonesia. Journal of Geoscience Engineering, Environment, and Technology (JGEET) Vol. 5 (1): 47 - 55.

$12 \mathrm{Li}$, Y., and Oldenburg, D.W., 1998. Separation of Regional and Residual Magnetic Field Data. Geophysics, 63(2), p. 431-439. 
13 Ilapadila, Herimei, B., and Maria, 2019. Analysis of Regional Anomaly on Magnetic Data Using the Upward Continuation Method. The International Conference on Geoscience. IOP Conf. Series: Earth and Environmental Science 279 (2019) 012037.

14 Telford W.M., Gedaart L.P, Sheriff R.E., 1990, Applied Geophysics, Cambridge University Press.

15 Subarsyah, Priohandono, Y.A., 2009. Metoda Pseudogravity dalam Analisis Kelurusan dan Patahan di Sekitar Tinggian Asahan, Perairan Selat Malaka. Jurnal Geologi Kelautan. Vol. 7 (2): $65-71$.

16 Asikin, S., dan Handoyo, A. 1992. Peta Geologi Lembar Banyumas, Jawa, Skala 1:100.000. Bandung: Pusat Penelitian dan Pengembangan Geologi (P3G).

17 Redaksi Ilmu Geografi, 2020. Batuan Breksi: Pengertian, Proses dan Jenisnya. Website. Tersedia di alamat https://ilmugeografi.com/geologi/batuan-breksi. Diakses pada tanggal 06 Nopember 2019.

18 Handika, S.N., 2018. Pendugaan Kedalaman Akuifer Menggunakan Teknik Vertical Electrical Sounding dan Perbandingannya dengan Hasil Bor di Desa Pekuncen Kecamatan Jatilawang Kabupaten Banyumas. Skripsi. Jurusan Fisika, Fakultas MIPA, Universitas Jenderal Soedirman. Purwokerto

19 Noor, D. 2012. Pengantar Geologi Edisi 2. Pakuan University Press, Bogor.

20 King, H.B., 2020. Basalt; What Is Basalt, How Does It Form, and How Is It Used. Website. Tersedia di alamat https://geology.com/rocks/basalt.shtml. Diakses pada tanggal 29 Mei 2020. 